\title{
Impact of Principal's Communication on Teacher Performance
}

\author{
Pepi Pramahsari ${ }^{1,2, *}$, Cepi Triatna ${ }^{1}$ \\ ${ }^{1}$ Educational Administration Department, School of Postgraduate Studies, ${ }^{2}$ Headmaster of Elementary School \\ ${ }^{1}$ Universitas Pendidikan Indonesia, ${ }^{2}$ Elementary School 3 Nagrikidul \\ ${ }^{1}$ Bandung, ${ }^{2}$ Purwakarta, Indonesia \\ *prahmasaripepi@gmail.com
}

\begin{abstract}
The essence of leadership is communication, as the results of existing research contribute to the performance of individuals in the organization. The purpose of this study is to test how significantly the influence of principal communication affects the performance of primary school teachers. Researchers used a quantitative approach to test the veracity of the proposed hypothesis. The data was taken through the distribution of questionnaires to 45 teachers in Purwakarta Regency. The data is then analyzed using regression techniques to obtain a large statistical influence. The findings showed that the principal's communication had a significant impact on teacher performance.
\end{abstract}

\section{Keywords-communication, principal, teacher performance}

\section{INTRODUCTION}

School as an organization certainly has organizational dynamics. Various organizational dynamics such as environment, human resource competence, managerial and leadership. One of the dynamics that is most often a concern in developing teacher competence is the communication process that occurs. Given the importance of teachers, teacher performance must always be improved. To improve their performance, teachers must have abilities that include performance, mastery of material, professional mastery of teacher and education, as well as mastery of ways of adapting themselves when carrying out tasks.

The reality on the ground is that the results of the achievements of the Purwakarta Regency Teacher Competency Test in 2019 show unexpected results. The results of the test for Elementary Schools still rank the lowest among several other districts in West Java.

The low performance of teachers as mentioned above is of course a common concern because there is a need for a stimulus to improve teacher performance. One of the factors that can improve teacher performance is the communication of the principal. Several studies have shown a significant relationship between principal communication and teacher performance [1-4]

Principal communication factors can improve teacher performance by conveying information that is needed by teachers. Communication is a process of delivering and receiving news or information from one person to another. Communication is an instrument used by humans in interacting with others, both in everyday life and in organizational life. In an organization, communication is a tool that functions as a liaison and motivation generator between each member so that an organization can move forward. An effective communication process is a prerequisite for the establishment of good cooperation to achieve organizational goals [5].

A proper communication will not occur, if the announcer does not convey the news properly and the recipient of the news does not receive it in the form of distortion. The form of communication can be seen from various points of view of each expert according to their experience and field of study. Communication is divided into four types, namely intrapersonal communication, interpersonal communication, public communication, and mass communication [4]. The ability to communicate and interact is very important in an organizational life, it even becomes a requirement. Communication within the organization becomes the central point in creating a conducive situation and environment, establishing continuous communication, increasing public trust, enhancing the organization's good image and even helping to promote and improve the marketing of a product / service [6].

Communication in a leadership is a very important element in achieving the success of the goals that will be achieved by an organization. Therefore, a leader must be good at communicating both verbally and non-verbally. Good communication will be able to increase motivation, so that the information conveyed can be received well and this will be able to improve performance and work supervision will also be carried out properly. In an organization the leader is a communicator. An effective leader generally has effective communication skills, so that more or less will be able to stimulate the participation of the people they lead [7].

Knowledge of the characteristics and leadership styles followed by leaders will contribute to communication problems [8]. There are several styles that can be applied by leaders in building communication, namely the following six main 
communication styles are operationalized: verbal aggressiveness, expressiveness, accuracy, certainty, support, and argumentative [9]. Communication by leaders is a guide for leaders in developing the ability to lead an organization. Leaders must create emotional intelligence and managerial communication to create models of communication skills and strategies to improve organizational quality. Leader communication can be started from developing strategies, analyzing audiences, writing all types of correspondence, and designing effective exposure for leadership perspectives [10]. After that, teachers as subordinates need to be guided about their emotional intelligence in organization, culturing literacy, meeting management and team leadership, all of which can be collaborated by means of internal and external communication. In order for the implementation of principal communication to be effective, principals must develop their self-awareness to become role models in organizations and learn to encourage differences of opinion in every communication relationship [11]. If the communication implemented by the principal goes well, then the teacher's performance will run well, because if there is a good relationship between leaders and subordinates, then the quality of the organization in the school will continue to be a reinforcement in every difference of view.

A number of previous studies have given no clear limits, and focus more on general organizations rather than educational organizations such as schools. Whereas in urgency this has something in common, that communication has an important role in encouraging teachers to improve better performance through the principal. Therefore, on this basis, researchers intend to fill the void of previous research with specific studies of educational organizations; primary school and seeks to uncover the influence of the principal's communication on teacher performance.

\section{METHODS}

This research was conducted in public elementary school Purwakarta District, Purwakarta Regency, totaling 45 schools. Through purposive sampling technique, from the existing population the researcher obtained a sample size of 123 respondents. The purpose of this study was to obtain the magnitude of the principal's communication influence on teacher performance according to teacher perceptions. So, in the method used, this study uses descriptive quantitative methods to explain the current phenomena. Communication in this researcher is studied through four indicators, that is: supportive, emotive, reflective, and directive [12].

The teacher performance in this study examines the professional ethics and literacy, teacher ability and development, and teacher performance and contributions. In extracting data, the researcher used a closed questionnaire, where the answer choices had been set by the researcher [13]. The data obtained by the researcher then through regression to obtain the magnitude of the influence of these variables.

\section{RESULTS AND DISCUSSION}

The results of data processing by regression indicate that principal communication has a significant positive effect on teacher performance in elementary school teachers. From table 1 , the regression coefficients shown are 0.819 and 0.699 on the principal's communication. This value means that if the principal's communication increases by 0.699 , it will have an increase in teacher performance by 0.819 . The complete results can be seen in the table below.

TABLE I. REGRESSION TEST

\begin{tabular}{|c|c|c|c|c|c|c|}
\hline & \multirow[t]{2}{*}{ Model } & \multicolumn{2}{|c|}{\begin{tabular}{|c|}
$\begin{array}{c}\text { Unstandardized } \\
\text { Coefficients }\end{array}$ \\
\end{tabular}} & \multirow{2}{*}{\begin{tabular}{|c|}
$\begin{array}{c}\text { Standardized } \\
\text { Coefficients }\end{array}$ \\
Beta \\
\end{tabular}} & \multirow[t]{2}{*}{$\mathbf{t}$} & \multirow[t]{2}{*}{ Sig. } \\
\hline & & $B$ & Std. Error & & & \\
\hline \multirow[t]{2}{*}{1} & (Constant) & .819 & .524 & & 1.562 & .121 \\
\hline & Principal Communication & .699 & .031 & .901 & 22.883 . & 3.000 \\
\hline
\end{tabular}

From the table above, the next information provided is the result of the $t$ test which is the basis for determining the significance of the influence of the research variables. Based on the results shown with a value of 22.883 and a value of Sig. of 0,000 indicates that the principal's communication has a significant effect on teacher performance. Based on this test, then the researcher wants to examine in more depth how strong the principal's communication is to determine teacher performance for teachers. Through the coefficient of determination test, the following results are obtained.

TABLE II. DETERMINATION TEST

\begin{tabular}{|l|l|l|l|l|}
\hline Model & \multicolumn{1}{|c|}{$\mathbf{R}$} & \multicolumn{1}{|c|}{$\begin{array}{c}\text { R } \\
\text { Square }\end{array}$} & \multicolumn{1}{c|}{$\begin{array}{c}\text { Adjusted } \\
\text { R Square }\end{array}$} & $\begin{array}{c}\text { Std. Error } \\
\text { of the Estimate }\end{array}$ \\
\hline 1 & $.901^{\mathrm{a}}$ & .812 & .811 & .97753 \\
\hline
\end{tabular}

From the above test, the coefficient of determination in the $\mathrm{R}$ square column is 0.811 or $81.1 \%$ if it is a percentage. With this value, it can be explained that the principal's communication strongly determines the improvement of teacher performance in elementary school teachers. Principal communication in a supportive, emotive, reflective, and directive manner can stimulate teachers to give their best performance in school.

The principal's communication as mentioned above has a significant influence on improving teacher performance in primary school teachers. The principal's communication is the process of sending information (message) to the teacher and can carry out the information to the protégé. The principal as a source of information in the school is needed by the teachers, so that the conveyed can be carried out for the development of the teacher itself as well as for the students. Communication is a basic human activity. The importance of communication for people cannot be felt nor can it be for an organization such as a 
school. Therefore, principals need to understand and improve their communication skills.

The communication process is essentially the process of conveying one's thoughts or feelings (communicators) to others (communion). Thoughts can be ideas, information, opinions, etc. that come out of his mind. Feelings can be beliefs, certainties, doubts, worries, anger, courage, excitement, and so on arising from the bottom of the heart. Communication will succeed if the mind is conveyed using a conscious feeling, instead communication fails if while conveying thoughts, uncontrolled feelings [14]. Message delivered in the communication process is realized through symbols or symbols in general in the form of words, images, and gesture actions such as gestures, nods, eye movements, and raising eyebrows.

The principal's communication in improving teacher professionals is to convey a message to teachers and teachers can carry out that information to students. The principal as a teacher should be able to provide guidance to all school residents and be able to perform his duties and functions as a school manager in improving the learning process through classroom supervision, fostering and giving positive advice to teachers. The duties of professional teachers, namely being able to carry out: the administrative duties of the curriculum and its development, the management of students, personnel, facilities and infrastructure, finance, special services, and public-school relations [15].

Principals who seek to foster relationships with teachers have the opportunity to improve teacher performance better. Through this relationship the principal can provide direction and offer some innovations to teachers in order to improve the quality of learning that directly impacts the teacher's performance. The efforts made by the principal in improving teacher performance are seen from several things namely trainings, teacher deliberations subjects, workshops, seminars, discipline and communication and interaction.

The primary responsibility of teachers is to carry out a quality learning process to improve students' learning performance. Responsibilities in learning are the main tasks for the teacher profession, including: as a teacher, mentor, classroom administrator, curriculum development, professional development and fostering public relations.

Building communication that can affect teacher performance is not easy. Requirements that should be considered by the principal to achieve the purpose of communication appropriately in order for changes in the direction and behavior of the teacher. Teacher performance is not only on the achievement of the results of teaching assignments, but also with regard to the behavior of an educator seen and exemplified by students in the school. teacher performance in learning is the most important part in supporting the creation of an effective education process, especially in building discipline and quality of students' learning outcomes. Good teacher performance can create effectiveness and efficiency of learning and can shape the discipline of students, schools and teachers themselves [14].
The principal's communication plays a big role in conveying a message to teachers to behave in a disciplined way. Work discipline leads to activities that educate teachers to comply with school rules. Forms of teacher discipline are timely attendance, teaching in accordance with learning planning, and compiling learning tools such as effective week details, learning plan, annual programs, semester programs, and minimum completed criteria. Through this work discipline, school activities can be carried out in an orderly and smooth manner. The development of work discipline can be said as a system of discipline enforcement that takes place continuously and dynamically. The efforts taken by the principal in addressing the problem of teachers who are less disciplined are by calling the teacher personally to be counseled, so as not to negatively impact other teachers, and are invited together to improve discipline so that it can be exemplified by students.

The principal's communication in improving the responsibility of teachers is inter-personal communication and communication in solving problems that may arise in learning in order to improve students' learning performance. Forms of teacher responsibility in learning, include: as a teacher, mentor, classroom administrator, curriculum development, professional development and fostering public relations. The teacher is also responsible for all attitudes, behaviors, practices of the protégé, responsibility towards him, his colleagues, principals, parents of students and others [16].

In discipline there are elements including code of conduct, consistent regulation, punishment and reward. The offence seems to have been considered commonplace, even worse the perpetrators did not feel guilty or guilty. Discipline is essentially the ability to control yourself in the form of not committing an act that is inappropriate or contrary to something that has been established. Teachers should be able to foster discipline in students, especially self-discipline.

The ability to communicate the principal is expected to improve the quality of the task execution, gather and accommodate various opinions and complaints, give and receive each other and the relationship and kinship is getting better. The nature of openness is very decisive between the two, the communication is very closely related to the discipline of teachers in teaching activities of students

The principal's communication in improving teacher discipline is to convey the resources in the school that are needed by the teachers, so that the information conveyed can be carried out. These forms of communication fill each other out, meaning to communicate from heart to heart in certain moments and places, in addition to conducting weekly meetings [17]

Effective communication implementation can prevent schools from adverse conflicts. Principals and teachers need to develop an attitude of openness and mutual respect and this can be achieved if there is good communication, this is done to avoid unpleasant things on both sides. Thus the leadership should be able to create a pleasant communication climate by giving teachers the opportunity to express ideas, suggestions of 
communication, teachers can obtain clear information and guidance so as not to cause doubt and misunderstanding that exists so as to affect the effectiveness of the teacher's work and their feelings in decision making.

Communication between school personnel must always be developed, both by the principal and by teachers and other personnel. Communication flows within the organization include vertical communication and horizontal communication. A vertical communication is the sending and receiving of messages between the levels of a hierarchy that is down and up. Downward communication takes place when the boss of an organization sends a message to his subordinates in this study that is from the principal who conveys the message to the teacher. The flow of communication upwards occurs when the subordinate sends a message to his boss, namely the teacher to the principal related to the duties and responsibilities of the work. Meanwhile, horizontal communication flow is the sending and receiving of messages between individuals at the same level in a hierarchy. Horizontal communication takes place between subordinates who have equal standing, namely fellow teachers and other staff.

\section{CONCLUSION}

The conclusion of this study is that teacher performance can be improved through communication conducted by the principal. Principals can apply various approaches in communicating vision, mission, and work programs to teachers in order to participate and carry out according to the instructions given. The communication approach can be supportive, emotive, reflective, and directive according to the condition and characteristics of the teacher. These four communication approaches need to be mastered by the principal so that there is no monotonous and balanced communication pattern, when to use supportive, directive, emotive, and reflective communication.

\section{REFERENCES}

[1] C. Rahawarin and S. Arikunto, "Pengaruh Komunikasi, Iklim Organisasi Dan Gaya Kepemimpinan Transformasional Kepala Sekolah Terhadap Kinerja Guru SMA,"J. Akuntabilitas Manaj. Pendidik. 2015.
[2] O.D. Putri, "Pengaruh Komunikasi Interpersonal dan Gaya Kepemimpinan Kepala Sekolah terhadap Kinerja Guru SMK Negeri 1 Jogonalan Klaten," Pendidik. Adm. Perkantoran, 2012

[3] M. Yodiq, "Peran Komunikasi Interpersonal Kepala Sekolah terhadap Motivasi Kerja Guru di Sekolah Menengah Atas Islam Samarinda," ejournal Ilmu Komun., 2016.

[4] M. Mudena, S. Wilian, and S. Sukardi, "Pengaruh Komunikasi Kepala Sekolah Dan Iklim Kerja Organisasi Sekolah Terhadap Kinerja Guru SD Negeri Di Kecamatan Mataram Kota Mataram,” J. Ilm. Profesi Pendidik., 2017.

[5] K. Mulawarman and Y. Rosilawati, "Komunikasi Organisasi," J. Ilm. Komun. Makna, 2014

[6] F.W. Lubis, "Peranan Komunikasi Dalam Organisasi," J. Harmon. Sos., 2008.

[7] E. Zahara, "Peranan Komunikasi Organisasi Bagi Pimpinan Organisasi," J. War., 2018.

[8] B. Zulch, "Leadership Communication in Project Management," Procedia - Soc. Behav. Sci., 2014.

[9] R. E. de Vries, A. Bakker-Pieper, and W. Oostenveld, "Leadership = communication? The relations of leaders' communication styles with leadership styles, knowledge sharing and leadership outcomes,” J. Bus. Psychol., 2010.

[10] J. Mayfield and M. Mayfield, "Leadership Communication,” Int. J. Bus. Commun., 2017.

[11] D. Clutterbuck and S. Hirst, "Leadership communication: A status report," Journal of Communication Management. 2002.

[12] G.F. Ross, "Book Reviews : B. L. Reece and R. Brandt (1993) Effective Human Relations in Organizations (5th edn) Boston: Houghton Mifflin Co,” Asia Pacific J. Hum. Resour., 1996.

[13] S.S. Weng, Y. Liu, and Y.C. Chuang, "Reform of Chinese universities in the context of sustainable development: Teacher evaluation and improvement based on hybrid multiple criteria decision-making model," Sustain., 2019.

[14] J.E. Brophy and T.L. Good, "Teachers' communication of differential expectations for children's classroom performance: Some behavioral data," J. Educ. Psychol., 1970.

[15] "The Relationship of Interpersonal Communication, Organizational Commitment and Supervision to Principal's Performance," Int. J. Manag. Stud. Res., 2016.

[16] H. Ärlestig, Communication between principals and teachers in successful schools. 2008.

[17] A.J.W. Mahri and M.A. Ramdhany, "The Influence of Principal's Leadership on Teachers' Competency, Motivation and Job Satisfaction, and Its Implication on Teachers' Performance in West Java," J. Pendidik. Bitara UPSI, 2013. 